\title{
Effect of Crude Oil Products on the Mechanical Characteristics of Reactive-Powder and Normal-Strength Concrete
}

\author{
Wisam K. Tuama', Mohammed M. Kadhum¹, Nameer A. Alwash'1, Zainab S. Al-Khafaji2,3, \\ Mustafa S. Abdulraheem ${ }^{1 *}$ \\ ${ }^{1}$ Department of Civil Engineering, Babylon University, College of Engineering, Babylon, 9CV2+23 Hilla, Iraq \\ 2 Al-Furat Al-Awsat Distribution Foundation, Ministry of Oil, Babylon, Iraq \\ ${ }^{3}$ Department of Civil Engineering, Al-Mustaqbal University College, Babylon, 9CW3+4G Hilla, Iraq \\ *Corresponding author, e-mail: stud.mustafa.siham@uobabylon.edu.iq
}

Received: 14 January 2020, Accepted: 28 February 2020, Published online: 23 March 2020

\begin{abstract}
This study includes detailed information on the mechanical characteristics of the hardened concrete mix for normal concrete (NSC) and reactive powder concrete (RPC) after exposure to crude oil products. Two types of crude oil products (kerosene and gas oil) were investigated after exposure for a period of 180 days. The experimental program consisted of three sets of NSC and RPC specimens; after curing all concrete specimens for 28 days and 2 days to dry in the air, the first set of specimens was immersed in kerosene for 180 days and the second set was immersed in gas oil for the same age, while the third set was left in the air as a reference set (cured normally for 28 days and tested at the age of 180 days). The results showed that the mechanical characteristics of the RPC mix were not highly affected after exposure to each type of crude oil products, where it lost about (3.41-6.32 \%) compared with reference RPC mix. While the NSC mix lost about (13.82-21.95\%) of its mechanical characteristics compared with reference NSC mix after exposure to crude oil products for the same period.
\end{abstract}

Keywords

crude oil, crude oil storage tanks, normal concrete (NSC), Reactive Powder Concrete RPC, durability, permeability

\section{Introduction}

The concrete durability in various environments is catching more attention recently as the consumption of concrete has increased significantly around the world. Designers try to design concrete structures with long term performance and good serviceability. Nevertheless, up to the current day just rather limited investigations about the performance of concrete in the physicochemical environments with organic active polar molecules such as crude oil.

Crude oil is a combination of hydrocarbons produced by animals and plants, which existed thousands of years ago. Crude oil seems to be a fossil fuel that occurs in liquid shape in deep reservoirs or pools, in small areas in sedimentary rocks, and also in tar (or oil) sands near the surface. It was sent to a refinery already when crude oil is lifted from either the ground, in which various parts of crude oil are split up into functional products of petroleum. Other products of petroleum involve asphalt, lubricating oils, waxes, petrochemical feedstock, jet fuel, distillate oil, diesel fuel, and coal [1].
On the other hand, the activity of oil on concrete is as yet fuzzy and the ongoing huge development of raw oil exploration from the Middle East nations and the seaward fields (North Sea), together with the issues emerging edge transportation and capacity require a quantitative investigation of the features of concrete in contact with oil. Recent experimental works have revealed that the impact of petroleum products on concrete is categorized either as non-destructive or only slightly destructive. Nevertheless, there is an indication that these products can cause a serious deterioration in concrete structures in contact with it $[1,2]$.

Oiling of structural elements is an issue that appeared in industrial buildings. Recently, damages were found in concrete oil storage containers. Heavily oiled concrete floors show great damage that mostly impairs the exploitation of buildings [3]. This damage depends on the concrete quality and its density [4]. Most authors have considered the permeability of concrete as a direct measure of its 
durability against harmful liquids [5-8]. The permeability of concrete is strongly affected by the pore structure and the presence of cracks and micro-cracks in the microstructure of concrete [9].

In general, normal strength concrete is well known as having inherent features of low tensile strength and a tendency to crack under different external tensile stresses. In most cases, long term loading extends the magnitude of cracks in both plain and reinforced concrete [1, 10]. Thus the serviceability of reinforced concrete storage containers necessitates controlling of cracking and impermeability and finding a better material with nearly impermeable characteristics to construct oil containers.

Reactive powder concrete (RPC) is described as a fiberreinforced, super-plasticized, impermeable material, which contains elevated dosages of cement and silicate fumes, a low water/binding ratio, and quartz sand with very fine particles $(0.15-0.60 \mathrm{~mm})$ rather than a regular aggregate. To advance the impermeability and microstructure of the RPC, coarse aggregate is eliminated to decrease heterogeneity between the aggregate and the cement matrix. Nevertheless, as a result of the elimination of coarse aggregate and the utilizing of sand with very fine particles, the cementitious materials utilized in RPC are as high as $\left(900-1200 \mathrm{~kg} / \mathrm{m}^{3}\right)$ [2].

Adding silica-fume to the concrete mixture enhances compressive strength and abrasion resistance of hardened concrete, decreases permeability and improves corrosion resistance to steel reinforcement. It fills the remaining voids as a micro-filler between fine aggregates and cement. Improving the transition zones of interfacial between fibers and binders also between aggregates and binder which is another important impact of silica fume. It also produces extra calcium-silicate-hydrate by the pozzolanic reaction between calcium hydroxide extracted from the process of Portland cement hydration and silica fume which therefore enhances the bond between aggregates and cement paste, thus enhancing the final strength [11]. RPC as an ultra-high-performance fiber reinforced concrete(UHPFRC) is catching more attention nowadays due to its durability and extraordinary strength characteristics [1, 12, 13]. Lately, many researchers have illustrated that the utilizing of steel fibers as reinforcement has brought good results to overcome the fragility of concrete [12, 14-17]. Thus, UHPFRC is a good alternative option to construct oil containers for its excellent properties including high-pressure resistance and tensile resistance in addition to its impermeable characteristics [1, 18-21].
Ajagbe et al. [22] examined the influence of impacted sand by crude oil (COIS) on the concrete compressive strength. Concrete mixing, 1:1.8:2.7 has been designed with $0.5 \mathrm{w} / \mathrm{c}$ for all specimens. Crude oil $(2.5,5,10,15,20$ and $25 \%$ ) by sand's weight has been utilized to contaminate the sand for the COIS concrete preparation. $147 \mathrm{spec}-$ imens of $100 \mathrm{~mm}$ cubes of concrete were investigated (21 controls and 126 contaminated specimens). The cubes were tested at the ages of $3,7,14,28,56,84$, and 168 days to determine the compressive strengths. COIS concrete specimens demonstrated a slow increase in strength and a decrease in the final strength value in comparison with control specimens.

Faiyadh [23] studied the mechanical characteristics of oil-saturated concrete. The test results indicated that the mechanical properties of the hardened concrete, mortar, and cement paste have been adversely affected by oil saturating. The modulus of elasticity and the compressive-strength have been decreased by amounts depending on the absorbed oil amount. In addition, the tensile-strength has been decreased but the reduction was less than the compressive strength and elastic modulus.

Though many studies have been conducted on RPC [12, 13, 24-27], the impact of crude oil products on RPC remains unclear as there is a lack of information about the reaction between these products and concrete. The aim of our work is to further the knowledge about the impact of crude oil products on the mechanical characteristics of RPC.

\section{Experimental work}

\subsection{Materials}

\subsubsection{Cement}

The cement utilized in this project is Ordinary Portland cement Type I (CEM 11/A-L 42.4R), which produced in the north of Iraq and known commercially as Karasta. This cement complies with the requirement of (EN 1971:2011) [28], the chemical and physical test results are demonstrated in Tables 1 and 2 respectively. Test results were conducted in University of Babylon, Civil Engineering Department Laboratories.

\subsubsection{Fine aggregate}

The sand utilized in this work was natural sand from Al-Ekhaidhir region, Iraq. The grading of the fine aggregate utilized is illustrated in Table 3. The results illustrate that the grading of fine aggregate after omitting the large size of the particle $(>600 \mu \mathrm{m})$ was within the Iraqi Specification 
Table 1 Composition and compounds chemically for Karasta cement

\begin{tabular}{|c|c|c|}
\hline Chemical Composition & $\begin{array}{l}\text { Percentage } \\
\text { by Weight }\end{array}$ & $\begin{array}{c}\text { Limit of } \\
(\text { EN 197-1:2011) }\end{array}$ \\
\hline Lime $(\mathrm{CaO})$ & 62.79 & - \\
\hline Silica $\left(\mathrm{SiO}_{2}\right)$ & 20.58 & - \\
\hline Alumina $\left(\mathrm{Al}_{2} \mathrm{O}_{3}\right)$ & 5.6 & - \\
\hline Iron Oxide $\left(\mathrm{Fe}_{2} \mathrm{O}_{3}\right)$ & 3.28 & - \\
\hline Magnesia $(\mathrm{MgO})$ & 2.79 & $5 \% \max$ \\
\hline Sulfate $\left(\mathrm{SO}_{3}\right)$ & 2.35 & $\begin{array}{l}2.5 \text { if } \mathrm{C} 3 \mathrm{~A} \leq 5 \\
2.8 \text { if } \mathrm{C} 3 \mathrm{~A}>5\end{array}$ \\
\hline Chloride content & 0.02 & $\leq 0.10 \%$ \\
\hline Loss on Ignition (L.O.I.) & 1.94 & $5 \% \max$ \\
\hline Insoluble Residue (I.R.) & 1.00 & - \\
\hline Lime Saturation Factor (L.S.F.) & 0.9 & - \\
\hline \multicolumn{3}{|l|}{ Main Compounds (Bogue's Equation) } \\
\hline Tricalcium Silicate $\left(\mathrm{C}_{3} \mathrm{~S}\right)$ & 50.12 & - \\
\hline Dicalcium Silicate $\left(\mathrm{C}_{2} \mathrm{~S}\right)$ & 21.26 & - \\
\hline Tricalcium Aluminate $\left(\mathrm{C}_{3} \mathrm{~A}\right)$ & 9.29 & - \\
\hline Tetracalcium Aluminoferrite $\left(\mathrm{C}_{4} \mathrm{AF}\right)$ & 9.98 & - \\
\hline
\end{tabular}

Table 2 Physical Karasta cement characteristics

\begin{tabular}{lcc}
\hline Physical Properties & Test Result & $\begin{array}{c}\text { Limit of } \\
(\text { EN 197-1:2011) }\end{array}$ \\
\hline $\begin{array}{l}\text { Specific Surface Area } \\
\text { (Blaine Method) } \mathrm{m}^{2} / \mathrm{kg}\end{array}$ & 314 & \\
Initial Setting, (hr : min) & 122 & $\geq 45 \mathrm{~min}$ \\
Final setting, (hr : min) & $3: 13$ & $\leq 10 \mathrm{hrs}$ \\
Soundness Using Autoclave Method & 0.61 & $\leq 10 \mathrm{~mm}$ \\
Compressive Strength at: & & \\
2 Days (MPa) & 21.0 & $>20$ \\
28 Days (MPa) & 45.8 & $\leq 42.5$ \\
\hline
\end{tabular}

requirements (IQS No.45/1984) [29]. The physical tests of fine aggregate that involve specific gravity, absorption, fineness modulus, sulfate content and content of fine materials are given in Table 4. These results are according to the Iraqi Specification requirements (IQS No.45/1984) [29].

\subsubsection{Silica fume}

The silica fume utilized in this study is produced by the chemical company (CONMIX), commercially called Mega Add MS (D). It is a gray-colored powder with a particle size that varies from $0.1 \mu \mathrm{m}$ to $1 \mu \mathrm{m}$. The average particle size is (100) times lower than that of portland cement in terms of particle diameter size. The silica fume is manufactured in accordance with the requirements of (ASTM C1240-15) [30]. The silica fume is utilized for space-filling, rheology enhancement, and secondary hydrate production. This is due to the enhancement in
Table 3 Fine sand grading results associated with requirements of (IQS no.45/1984) [29]

\begin{tabular}{lcc}
\hline $\begin{array}{l}\text { Size of the Sieve } \\
(\mathrm{mm})\end{array}$ & $\begin{array}{c}\text { Cumulative } \\
\text { Passing }\end{array}$ & $\begin{array}{c}\text { Limits of IQS No.45/1984 } \\
\text { as in (Zone 4) }\end{array}$ \\
\hline 10 & 100 & 100 \\
4.75 & 100 & $95-100$ \\
2.36 & 100 & $95-100$ \\
1.18 & 100 & $90-100$ \\
0.60 & 100 & $80-100$ \\
0.30 & 40 & $15-50$ \\
0.15 & 11 & $0-15$ \\
\hline
\end{tabular}

Table 4 Chemical and Physical characteristics for utilized sand Physical features

\begin{tabular}{lcc} 
Features & $\begin{array}{c}\text { Test } \\
\text { Results }\end{array}$ & $\begin{array}{c}\text { Iraqi Specification } \\
\text { Vo.45/1984 }\end{array}$ \\
\hline $\begin{array}{l}\text { Specific Gravity } \\
\text { Absorption }\end{array}$ & 2.65 & - \\
$\begin{array}{l}\text { Fine Material Passing from } \\
(75 \mu \mathrm{m}) \text { Sieve }\end{array}$ & $3 \%$ & - \\
$\begin{array}{l}\text { Fineness Modulus } \\
\text { Chemical Properties }\end{array}$ & Max $\leq 5.0 \%$ \\
Sulfate Content & $0.344 \%$ & Max $\leq 0.5 \%$ \\
\hline
\end{tabular}

Table 5 Chemical analysis of the utilized silica fume

\begin{tabular}{lcc}
\hline $\begin{array}{l}\text { Oxide } \\
\text { Composition }\end{array}$ & Oxide Content \% & $\begin{array}{c}\text { ASTM C1240-15 } \\
\text { Limitations }\end{array}$ \\
\hline $\mathrm{SiO}_{2}$ & 89.41 & Min. $85 \%$ \\
$\mathrm{Al}_{2} \mathrm{O}_{3}$ & 0.63 & - \\
$\mathrm{Fe}_{2} \mathrm{O}_{3}$ & 0.45 & - \\
$\mathrm{CaO}$ & 0.82 & $<1$ \\
$\mathrm{So}_{3}$ & 0.87 & $<2$ \\
$\mathrm{~K}_{2} \mathrm{O}+\mathrm{Na}_{2} \mathrm{O}$ & 1.35 & - \\
$\mathrm{L} . \mathrm{O} . \mathrm{I}$ & 4.10 & Max. $6 \%$ \\
$\mathrm{CI}$ & 0.18 & - \\
$\mathrm{CaO}($ free $)$ & 2.15 & - \\
\hline
\end{tabular}

Table 6 Physical properties of silica fume used

\begin{tabular}{lcc}
\hline Physical Properties & Result & ASTM C1240- 15 \\
\hline Strength activity index & $130 \%$ & $\geq 105$ \\
$\begin{array}{l}\text { Percent retained on } 45 \mu \mathrm{m} \\
(\text { No.325) sieve, } \max , \%\end{array}$ & 1.7 & $\leq 10$ \\
Specific Surface, Min, $\left(\mathrm{m}^{2} / \mathrm{g}\right)$ & 23 & $\geq 15$ \\
\hline
\end{tabular}

the densification of the cement matrix and also to the enhancement of the bonding between the aggregates and the cement paste in the interfacial area.

Tables 5 and 6 show the characteristics, analyzing the chemical composition and physical requirements respectively of the silica fume utilized in this project with a comparison with (ASTM C1240-15) requirements [30]. 


\subsubsection{Water}

Tap water was used for producing and curing of concrete specimens in the experimental work of this research. The temperature $\left(25 \pm 2{ }^{\circ} \mathrm{C}\right)$ of water was maintained.

\subsection{Concrete mix design}

The quantities of constituents of NSC and RPC mixtures were selected after several preliminary mixtures were made. The quantities were as illustrated in Table 7. The ordinary Portland cement type 1 was utilized in both mixtures. In RPC mix, the sand was utilized with a maximum size of $0.6 \mathrm{~mm}$, silica fume utilized was according to ASTM C1240-15 [30] and the fibers length was $13 \mathrm{~mm}$ and diameter $0.2 \mathrm{~mm}$, the plasticizer polycarboxylic polymers was also utilized in this examination as high range water reducing admixture (superplasticizer) which conforms to the ASTM C494/C494M-17 [31].

\subsection{Exposure to crude oil products}

Two types of oil products were utilized in the present investigation (kerosene, and gas oil). They were obtained from (Al-Durra Refinery), produced locally in Iraq, and stored in an airtight steel and plastic containers to avoid losses and contamination. Table 8 illustrates the characteristics of the oil products utilized.

Table 7 NSC and RPC mix design for $1 \mathrm{~m}^{3}$ concrete

\begin{tabular}{lcc}
\hline Constitutive Type & \multicolumn{2}{c}{ Mix Proportion } \\
& (RPC) & (NSC) \\
\hline Cement $\left(\mathrm{kg} / \mathrm{m}^{3}\right)$ & 980 & 456 \\
Sand $\left(\mathrm{kg} / \mathrm{m}^{3}\right)$ & 10504 & 776 \\
Gravel $(\mathrm{kg} / \mathrm{mv})$ & - & 825 \\
Silica Fume $\left(\mathrm{kg} / \mathrm{m}^{3}\right)$ & 245 & - \\
Steel Fiber $\left(\mathrm{kg} / \mathrm{m}^{3}\right)(2 \%)$ & 157 & - \\
W/cm & 0.16 & 0.5 \\
Super Plasticizer by Wt. of & 3.5 & - \\
Cementitious $(\%)$ & & \\
\hline
\end{tabular}

Table 8 Features of utilized crude oil products

\begin{tabular}{lcc}
\hline Oil Inspection Data & Kerosene Results & Gas oil Results \\
\hline humidity content \% by size & $0 \%$ & $0 \%$ \\
Sulfur content \% by weight & $0.2 \%$ & $1 \%$ \\
$\mathrm{pH}$ & 7.6 & 6.3 \\
Specific gravity $\left(\mathrm{g} / \mathrm{cm}^{3}\right.$ ) at: & 0.801 & 0.85 \\
Viscosity (centipoises) at 25C & 1.092 & 3.960 \\
Flash point (min) & 38 & 54 \\
Char value mg/kg (max) & 20 & - \\
Diesel index (min) & - & 55 \\
\hline
\end{tabular}

After the period of curing (28 days) is finished, the specimens were left in the air to dry for two days. The first set of specimens was then immersed in kerosene for 180 days and the second set immersed in the gas oil for the same period, while the third set was left in the air as a reference set (for comparison).

\subsection{Tests}

\subsubsection{Compressive strength}

Cubes specimens are utilized to test the compressive strength. Three cubes of $(50 \times 50 \times 50 \mathrm{~mm}$ for RPC and $150 \times 150 \times 150 \mathrm{~mm}$ for NSC) are utilized for each test results and the average of these three cubes is taken as the reading for a single age. Compressive strength is tested at the age of 7, 28 and 180 days according to ASTM C109/ C109M-16 [32].

\subsubsection{Splitting tensile strength}

For this test, cylinders of $150 \mathrm{~mm}$ in diameter and $300 \mathrm{~mm}$ in height are used for both RPC and NSC to test the tensile strength. Three cylinders are used in each age and the average of these three cylinders is taken as the reading for that particular age. Tensile strength is tested at the age of 7, 28 and 180 days according to ASTM C496-17 [33].

\subsubsection{Flexural test}

This test is utilized to identify material flexural-strength or flexural-modulus. This test is more reasonable compared with a tensile-test. The major benefit of a threepoint flexural test is the ease of specimens testing and preparing. Three prisms of $(50 \times 50 \times 300 \mathrm{~mm}$ for RPC and $100 \times 100 \times 400 \mathrm{~mm}$ for NSC) were tested for each outcome according to ASTM C 348-19 [34] at 7, 28 and 180 days.

\subsubsection{Modulus of elasticity}

The static modulus of elasticity was conducting on $(100 \times 200 \mathrm{~mm})$ cylindrical specimens and according to ASTM C469-14 [35]. For each specimen, the top surface was well finished and smoothed by using an electric grinding machine to prevent any loss of strength. The specimens were tested at ages (3, 7, 28 and 60 days) and the average of three specimens was taken for each test result.

\section{Results and discussion}

The most important visual implication during the testing process of concrete specimens was the discoloration of the concrete core after exposure to crude oil products for 180 days. The appearance of the NSC and RPC specimens 
after exposure to crude oil products is illustrated in Figs. 1 and 2. In addition, Fig. 3 illustrates the analysis of color change which was performed on the surfaces of the RPC specimens before and after exposure to crude oil products. The images obtained in Fig. 3, were taken after magnification with a macro lens $(25-58 \mathrm{~mm})$. It can be seen from this figure that after exposure to kerosene the specimen turned to a darkish grey color, while after exposure to gas oil, the discoloration progressed more notably as the concrete surface became darker and close to the black color. The mechanical characteristics of the hardened concrete conducted in this study consist of compressive resistance, splitting tensile resistance, flexural resistance, and modulus of elasticity. Those characteristics are investigated in order to estimate the resistance of RPC and NSC to crude oil products. RPC and NSC specimens were cured for 28 days and then left in the air to dry for two days. After that, the tested specimens were grouped

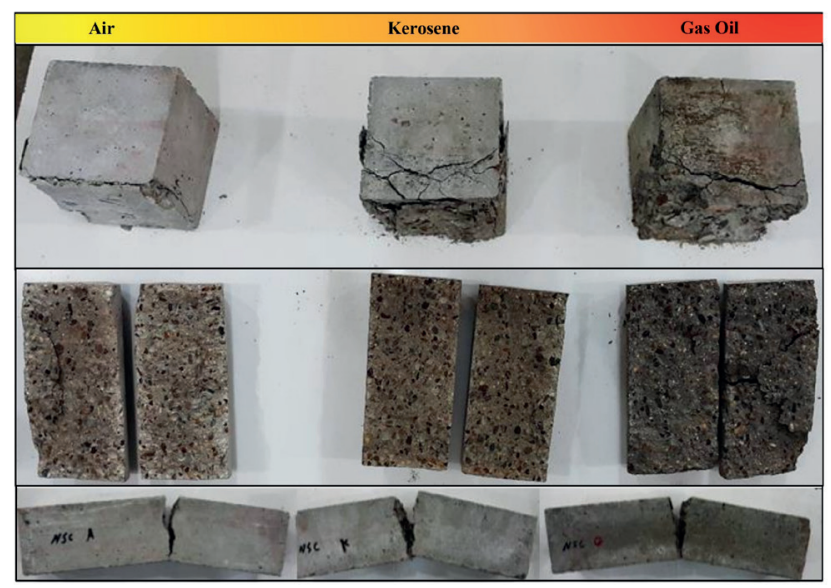

Fig. 1 the appearance of tested NSC specimens before and after exposure to crude oil products

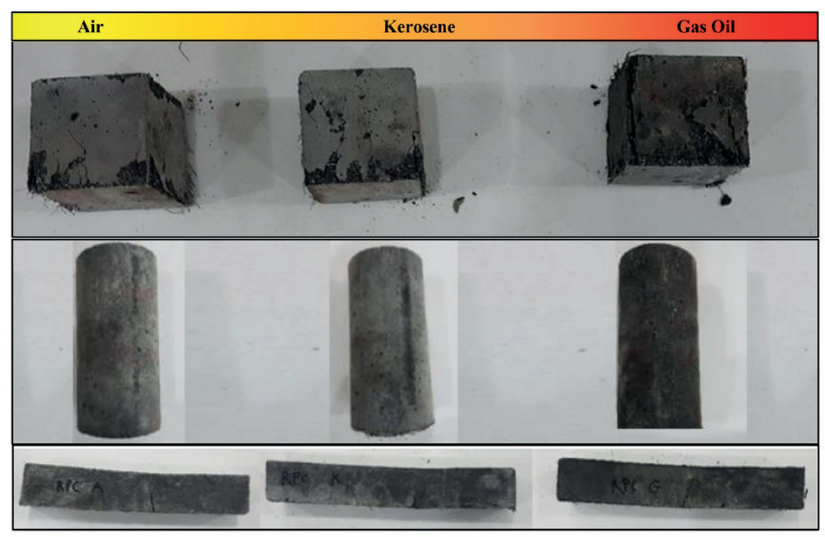

Fig. 2 the appearance of tested RPC specimens before and after exposure to crude oil products

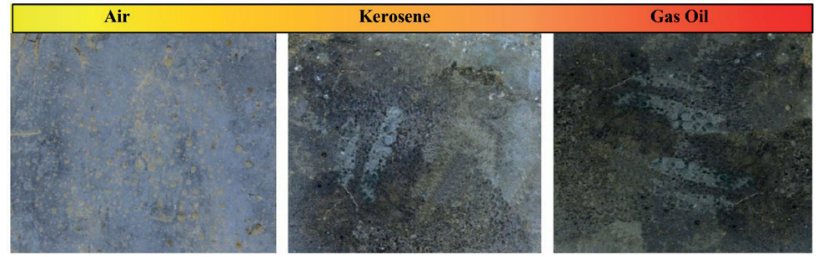

Fig. 3 discoloration analysis of tested RPC specimens before and after exposure to crude oil products

into three categories. The first one was cured in kerosene, meanwhile, the second one was cured with gas oil and the third one was left in air for 180 days. The overall measurement results of the mechanical characteristics for both RPC and NSC mixes are summarized in Table 9. Fig. 4 (a-d) displays the percentages of reduction and residual mechanical characteristics results of all investigated mixes for various exposure conditions. Each value in Fig. 4 reflects the average value of three specimens so as to reduce the error. This figure illustrates the values of the mechanical characteristics of the mixtures at the age of 180 days and comparisons between NSC and RPC mixtures in term of resistance to crude oil products. It can be seen from Fig. 4 that the reduction in the mechanical characteristics of RPC after exposure to crude oil products for 180 days was nearly negligible with the highest reduction of $6.32 \%$ compared with reference RPC mix. On the other hand, it can be seen from Table 9 and Fig. 4 that the mechanical characteristics of NSC specimens deteriorated significantly after exposure to crude oil products for the same period. NSC lost about (13.82-21.95\%) of its mechanical characteristics compared with reference NSC mix after exposure to crude oil products for the same period, see Fig. 4. It also can be seen from this figure that the reduction in the mechanical characteristics of the RPC and NSC specimens exposed to gas oil was slightly higher than that of kerosene. The most likely explanation is that in term of permeability, concrete acts as a "molecular sieve" in which the penetration depth of various liquids depends on the molecule size of it and permeability of concrete, which means that the water can penetrate deeper into the concrete pore system as compared with the larger molecule size crude oil products. Nevertheless, because RPC contains silica fume, which in turn increases the resistance of the concrete by forming the secondary gel and increasing the density of the concrete by reducing the pores, in addition to using a very small w/c percentage, oil products cannot penetrate into the concrete core deeply as in NSC. 

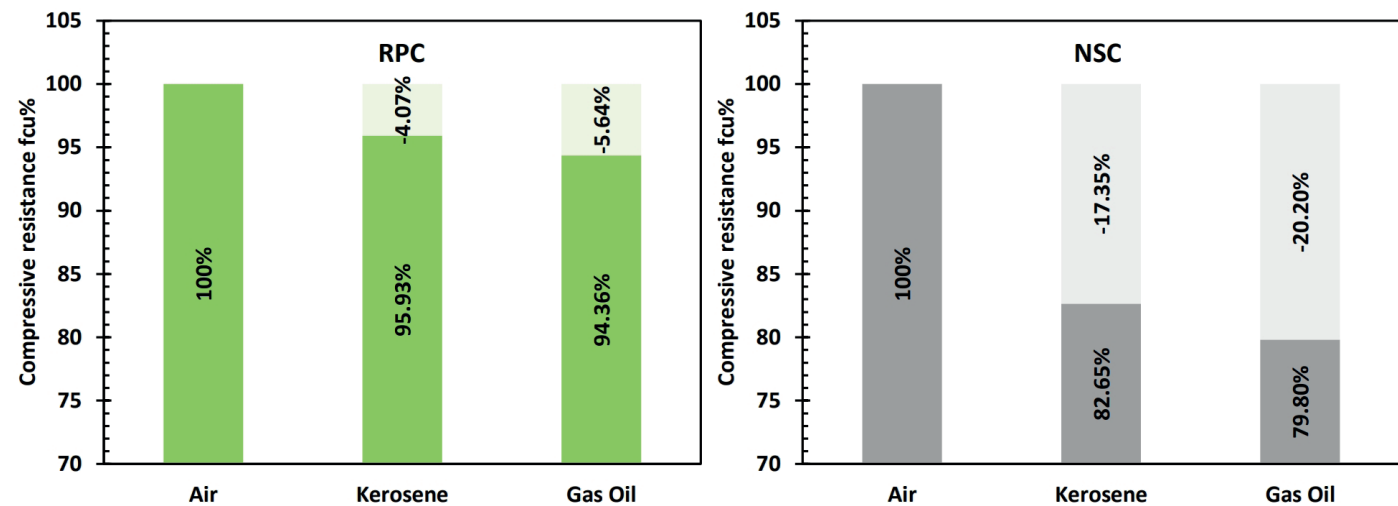

a) Compressive strength of RPC and NSC at the age of 210 days after exposure to crude oil products for 180 days
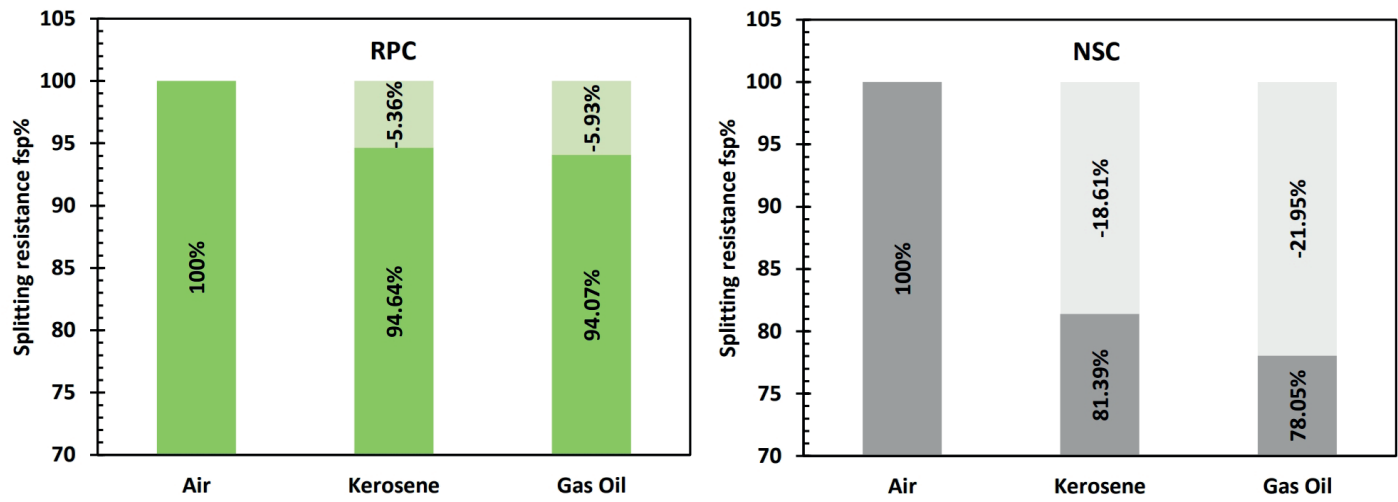

b) Tensile splitting strength at the age of 210 days after exposure to crude oil products for 180 days
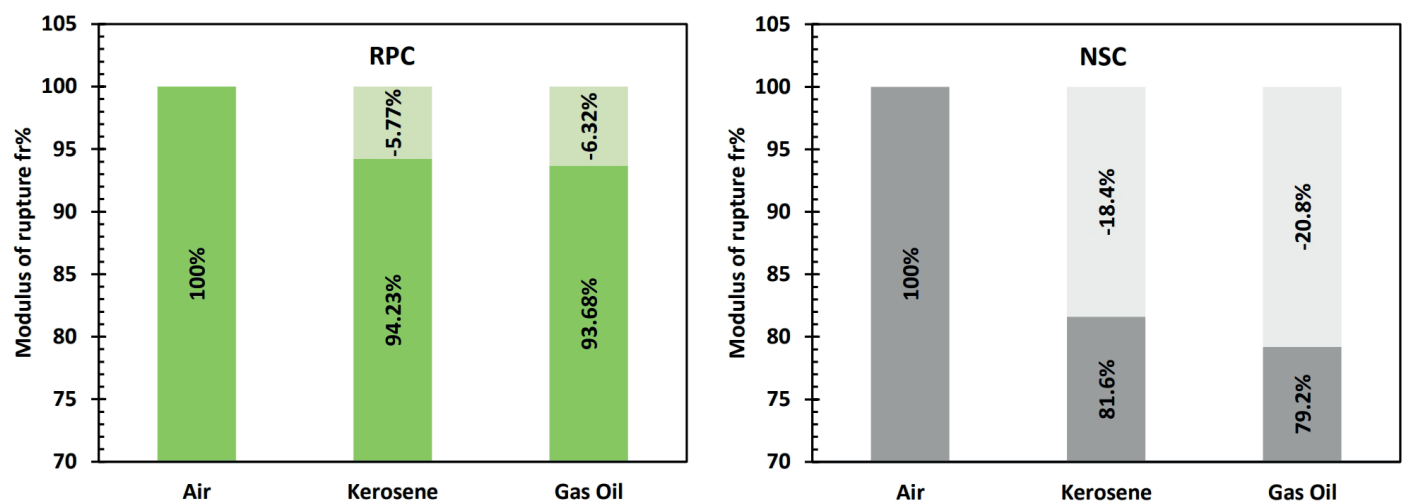

c) Modulus of rupture at the age of 210 days after exposure to crude oil products for 180 days
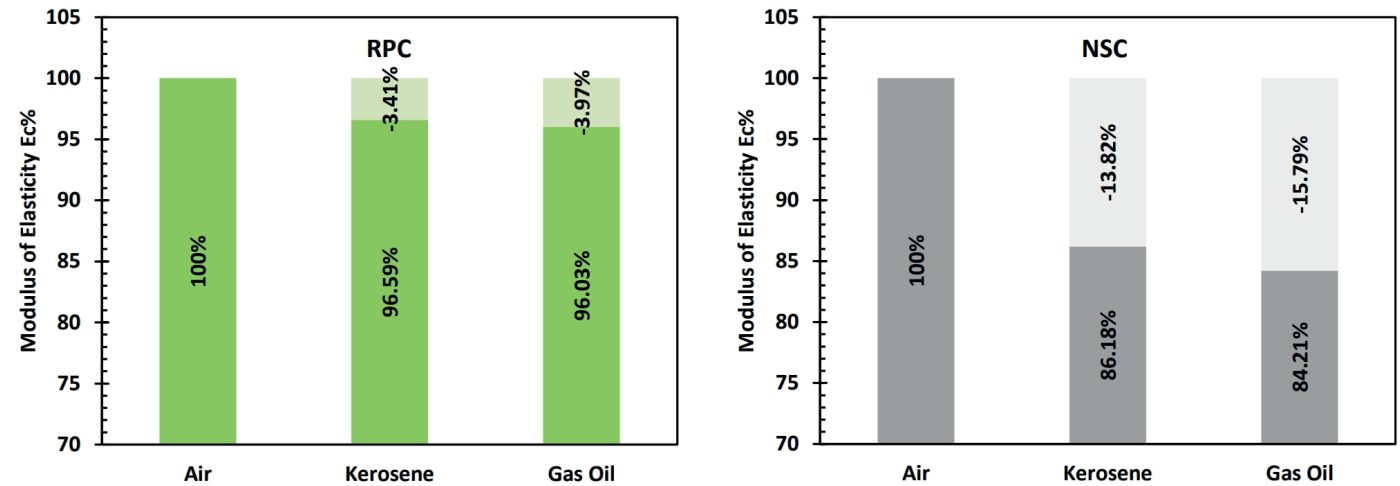

d) Modulus of elasticity at the age of 210 days after exposure to crude oil products for 180 days

Fig. 4 Percentages of reduction and residual mechanical characteristics of RPC and NSC specimens after exposure to crude oil products 
Table 9 Summary of the overall mechanical characteristics results for RPC and NSC specimens

\begin{tabular}{|c|c|c|c|c|c|c|c|c|c|c|}
\hline \multirow{2}{*}{$\begin{array}{l}\text { Type of Concrete } \\
\text { Age (days) }\end{array}$} & \multicolumn{5}{|c|}{$\mathrm{RPC}$} & \multicolumn{5}{|c|}{$\mathrm{NSC}$} \\
\hline & 7 & 28 & & 180 & & 7 & 28 & & 180 & \\
\hline & & & Air & Kerosene & Gas Oil & & & Air & Kerosene & Gas Oil \\
\hline Compressive strength (MPa) & 106.7 & 129.3 & 140.2 & 134.5 & 132.3 & 30.9 & 44 & 49 & 40.5 & 39.1 \\
\hline Splitting strength (MPa) & 8.2 & 11.75 & 14 & 13.25 & 13.17 & 2 & 2.9 & 3.6 & 2.93 & 2.81 \\
\hline Modulus of rupture (MPa) & 15.25 & 23.5 & 31.2 & 29.4 & 29.23 & 4.1 & 4.5 & 5 & 4.08 & 3.96 \\
\hline Modulus of Elasticity (GPa) & 42.3 & 45.7 & 47.32 & 45.71 & 45.44 & 25.13 & 29.2 & 30.9 & 26.63 & 26.02 \\
\hline
\end{tabular}

\section{Conclusions}

The impact of crude oil products on the mechanical characteristics of reactive-powder and normal-strength concrete was investigated. The experimental program consisted of three sets of NSC and RPC specimens; the first set of specimens was immersed in kerosene for 180 days and the second set was immersed in gas oil for the same age, while the third set was left in the air as a reference set. Depending on the aforementioned experimental investigation, the conclusions can be drawn as the following:

- The reduction in the mechanical characteristics of RPC after exposure to crude oil products for 180 days was insignificant, while NSC specimens deteriorated significantly after exposure to crude oil products for the same period, in which NSC lost about

\section{References}

[1] Kadhum, M. M., Alwash, N. A., Tuama, W. K., Abdulraheem, M. S. "Experimental and numerical study of influence of crude oil products on the behavior of reactive powder and normal strength concrete slabs", Journal of King Saud University - Engineering Sciences, (Accepted for publication March 2019) (in press) https://doi.org/10.1016/j.jksues.2019.03.007

[2] Błaszczyński, T. "Durability analysis of RC structures exposed to a physico-chemical environment", In: Proceedings of the Third International Conference on Global Trends in Structural Engineering, Singapore, 1994, pp. 67-70.

[3] Diab, H. "Compressive strength performance of low-and highstrength concrete soaked in mineral oil", Construction and Building Materials, 33, pp. 25-31, 2012.

https://doi.org/10.1016/j.conbuildmat.2012.01.015

[4] Ejeh, S. P., Uche, O. A. U. "Effect of crude oil spill on compressive strength of concrete materials", Journal of Applied Sciences Research, 5(10), pp. 1756-1761, 2009. [online] Available at: http:// www.aensiweb.com/old/jasr/jasr/2009/1756-1761.pdf [Accessed: 8 February 2020]

[5] Sigl, O., Mohanty, S. K., Krenn, F., Höfer-Öllinger, C. G., Rao, B. E., Babu, V. S., Kudtarkar, D. M., Nizalapur, M., Padiyar, P. S. "Underground Crude Oil Strategic Storage Projects in India", presented at Proceedings of the World Tunnel Congress 2014 - Tunnels for a better Life, Foz do Iguaçu, Brazil, May, 9-14, 2014. https://doi.org/10.13140/RG.2.2.34311.39840
(13.82-21.95 \%) of its mechanical characteristics compared with reference NSC specimens.

- The reduction in the mechanical characteristics of RPC and NSC specimens exposed to gas oil was slightly higher than that of kerosene after exposure for 180 days.

- Taken together, these findings implicate that RPC performs better as compared with NSC in term of external attacks of harmful liquids as RPC is nearly impermeable material.

- Future research on the topic using a scanning electron microscope (SEM) of RPC and NSC specimens which might extend the explanations of the concrete microstructure deterioration and the depth of the penetration of crude oil products.

[6] Ande, S., Berdanier, B., Ramakrishnan, V. "Performance of Reactive Powder Concrete Containing Arsenic", Journal of Water Resource and Protection, 3(5), pp. 335-340, 2011.

https://doi.org/10.4236/jwarp.2011.35042

[7] Boutiba, A., Chaid, R., Molez, L., Jauberthie, R. "Ripening in Chemically Aggressive Environment the HPC Reinforced with Hybrid Steel Fiber", Periodica Polytechnica Civil Engineering, 60(1), pp. 83-88, 2016.

https://doi.org/10.3311/PPci.7899

[8] Mlinárik, L., Kopecskó, K. "The influence of combined application of two SCMs on the corrosion and acid attack durability of mortars", Periodica Polytechnica Civil Engineering, 61(2), pp. 313-321, 2017. https://doi.org/10.3311/PPci.9352

[9] Albitar, M., Mohamed Ali, M. S., Visintin, P., Drechsler, M. "Durability evaluation of geopolymer and conventional concretes", 136, pp. 374-385, 2017. https://doi.org/10.1016/j.conbuildmat.2017.01.056

[10] Fawzi, N. M., AL-Ameer, S. A. A. "Effect of Petroleum Products on Steel Fiber Reinforced Concrete", Journal of Engineering Sciences, 19, pp. 13-34, 2013. [online] Available at: https://www.researchgate.net/publication/332333082_Effect_of_Petroleum_Products on_Steel_Fiber_Reinforced_Concrete [Accessed: 8 February 2020]

[11] ACI "234R-06: Guide for the use of silica fume in concrete", American Concrete Institute, Farmington Hills, MI, USA, 2006. 
[12] Abdulraheem, M. S., Kadhum, M. M. "Experimental and numerical study on post-fire behaviour of concentrically loaded reinforced reactive powder concrete columns", Construction and Building Materials, 168, pp. 877-892, 2018.

https://doi.org/10.1016/j.conbuildmat.2018.02.123

[13] Abdulraheem, M. S., Kadhum, M. M. "Experimental investigation of fire effects on ductility and stiffness of reinforced reactive powder concrete columns under axial compression", Journal of Building Engineering, 20, pp. 750-761, 2018. https://doi.org/10.1016/j.jobe.2018.07.028

[14] Chidambaram, R. S., Agarwal, P. "Seismic behavior of hybrid fiber reinforced cementitious composite beam-column joints", Materials and Design, 86, pp. 771-781, 2015.

https://doi.org/10.1016/j.matdes.2015.07.164

[15] Bentur, A., Mindess, S. "Fibre reinforced cementitious composites", CRC Press, Boca Raton, FL, USA, 2006.

[16] Wafa, F. F., Ashour, S. A. "Mechanical properties of high-strength fiber reinforced concrete", ACI Materials Journal, 89(5), pp. 449455, 1992.

[17] Kizilkanat, A. B. "Experimental evaluation of mechanical properties and fracture behavior of carbon fiber reinforced high strength concrete", Periodica Polytechnica Civil Engineering, 60(2), pp. 289-296, 2016. https://doi.org/10.3311/PPci.8509

[18] Nagayama, M., Miyashita, T. "Tensile Stress-Strain Relationship of High-Performance Fiber Reinforced Cement Composites", presented at The 14th World Conference on Earthquake Engineering, Beijing, China, Oct. 12-17, 2008.

[19] Park, S. H., Kim, D. J., Ryu, G. S., Koh, K. T. "Tensile behavior of ultra high performance hybrid fiber reinforced concrete", Cement and Concrete Composites, 34(2), pp. 172-184, 2012.

https://doi.org/10.1016/j.cemconcomp.2011.09.009

[20] Choi, Y., Yuan, R. L. "Experimental relationship between splitting tensile strength and compressive strength of GFRC and PFRC", Cement and Concrete Research, 35(8), pp. 1587-1591, 2005. https://doi.org/10.1016/j.cemconres.2004.09.010

[21] Gao, D., Liu, J. "Basic theory of steel fiber reinforced concrete", China Science and Technology Press, Beijing, China, 1994.

[22] Ajagbe, W. O., Omokehinde, O. S., Alade, G. A., Agbede, O. A. "Effect of Crude Oil Impacted Sand on compressive strength of concrete", Construction and Building Materials, 26(1), pp. 9-12, 2012. https://doi.org/10.1016/j.conbuildmat.2011.06.028

[23] Faiyadh, F. I. "Properties of oil saturated concrete", PhD Thesis, University of Sheffield, 1980. [online] Available at: https://core. ac.uk/download/pdf/77023273.pdf [Accessed: 8 February 2020]
[24] de Larrard, F., Sedran, T. "Optimization of ultra-high-performance concrete by the use of a packing model", Cement and Concrete Research, 24(6), pp. 997-1009, 1994.

https://doi.org/10.1016/00088846 (94)90022-1

[25] Hebel, K., Viviani, M., Denarié, E., Brühwiler, E. "Development of the mechanical properties of an Ultra-High Performance Fiber Reinforced Concrete (UHPFRC)", Cement and Concrete Research, 36(7), pp. 1362-1370, 2006.

https://doi.org/10.1016/j.cemconres.2006.03.009

[26] Graybeal, B. A. "Material Property Characterization of UltraHigh Performance Concrete", U.S. Department of Transportation Federal Highway Administration, McLean, VA, USA, Rep. FHWAHRT-06-103, 2006. [online] Available at: https://www.fhwa.dot.gov/ publications/research/infrastructure/structures/06103/06103.pdf [Accessed: 8 February 2020]

[27] Kadhum, M. "Prediction of Mechanical Properties of Reactive Powder Concrete by Using Artificial Neural Network and Regression Technique after the Exposure to Fire Flame", Jordan Journal of Civil Engineering, 9(3), pp. 381-399, 2015.

[28] BSI "BS. 197-1: 2011 Cement. Composition, specifications and conformity criteria for common cements", British Standard Institution, London, UK, 2011.

[29] Al-Nu'man, B. S., Aziz, B. R., Abdulla, S. A., Khaleel, S. E. "Effect of Aggregate Content on the Concrete Compressive Strength Ultrasonic Pulse Velocity Relationship", American Journal of Civil Engineering and Architecture, 4(1), pp. 1-5, 2016.

https://doi.org/10.12691/ajcea-4-1-1

[30] ASTM "C1240-15 Standard Specification for Silica Fume Used in Cementitious Mixtures", ASTM International, West Conshohocken, PA, USA, 2015.

[31] ASTM "C494 / C494M-17 Standard Specification for Chemical Admixtures for Concrete", ASTM International, West Conshohocken, PA, USA, 2017.

[32] ASTM "C109 / C109M-16 Standard Test Method for Compressive Strength of Hydraulic Cement Mortars (Using 2-in. or [50-mm] Cube Specimens)", ASTM International, West Conshohocken, PA, USA, 2016.

[33] ASTM "C496 / C496M-17 Standard Test Method for Splitting Tensile Strength of Cylindrical Concrete Specimens, ASTM International", West Conshohocken, PA, USA, 2017.

[34] ASTM "C348-19 Standard Test Method for Flexural Strength of Hydraulic-Cement Mortars", ASTM International, West Conshohocken, PA, USA, 2019.

[35] ASTM "C469 / C469M-14 Standard Test Method for Static Modulus of Elasticity and Poisson's Ratio of Concrete in Compression", ASTM International, West Conshohocken, PA, USA, 2014. 